\title{
A NEW METHOD FOR MEASURING AIRWAY RESISTANCE IN MAN USING A BODY PLETHYSMOGRAPH: VALUES IN NORMAL SUBJECTS AND IN PATIENTS WITH RESPIRATORY DISEASE ${ }^{1}$
}

\author{
By ARTHUR B. DuBOIS, STElla Y. BOTELHO, and JULIUS H. COMROE, Jr.
}

(From the Department of Physiology and Pharmacology, Graduate School of Medicine, University of Pennsylvania, Philadelphia, Pa.)

(Submitted for publication October 17, 1955; accepted December 5, 1955)

Satisfactory methods, utilizing measurements of transthoracic or transpulmonary pressure and airflow, are now available for determining "nonelastic" pulmonary resistance. However, the nonelastic pulmonary resistance has two components, tissue resistance and airway resistance, and no valid direct method is available for measuring either of these components separately in man. Since airway resistance is the ratio of alveolar pressure during flow to airflow, airway resistance alone could be measured if there were a method for determining alveolar pressure during flow. This report presents a new method for accomplishing this measurement, and gives data for airway resistance obtained in normal subjects and in patients with respiratory disease.

Of previous attempts to measure airway resistance, one of the earliest was the painstaking study by Rohrer (1) who made anatomical measurements on the tracheobronchial tree of a human lung post mortem and calculated the cumulative resistance to airflow of the entire system using Poíseuille's law and turbulence theory. The first important experimental study of pulmonary resistance in the living animal was made by von Neergaard and Wirz who, in 1927 (2), analyzed intrapleural pressure into two major components, "dynamic" (which is essentially resistive) and "static" (which is predominantly elastic in nature). This approach made it possible to obtain values for total pulmonary resistance, though not for airway resistance alone. Bayliss and Robertson (3), reasoning that airway resistance, but not tissue resistance, would vary with the viscosity of the gases breathed, ventilated isolated animal lungs with gases of different density and viscosity;

1 These studies were aided (in part) by a contract between the Office of Naval Research, Department of the Navy, and the University of Pennsylvania, NR 112-323. from the changes in pressure and volume during artificial ventilation with different gases, they calculated the fraction of non-elastic pulmonary resistance attributable to airway resistance. Studies based upon the revised principle of utilizing several different gas mixtures of different density and viscosity have been carried out more recently in man by Fry, Ebert, Stead, and Brown (4) and McIlroy, Mead, Selverstone, and Radford (5) who made the point that gas combinations which have equal kinematic viscosities should be selected. The results using this technique have been at variance to date, possibly owing to other factors affecting airway resistance (5).

A number of investigators have measured mouth pressure immediately after interruption of airflow with the belief that in such a static system, mouth pressure equals alveolar pressure. Von Neergaard and Wirz (6), Vuilleumier (7), Otis, Fenn and Rahn (8), and Mead and Whittenberger (9), using such a technique, found that brief interruption of the airstream gave a pressure at the mouth of about the same magnitude as the "dynamic" component of ventilatory pressure; however theoretically the alveolar pressure, after airflow has stopped, is not necessarily the same as before the airflow stopped, because there is adequate time for a major change in alveolar pressure to occur during the transition from flow to no flow (9). There are no measurements which compare alveolar pressure during interruption and during airflow because until now it has not been possible to measure alveolar pressure during airflow.

\section{METHOD}

Airway resistance $(R)$ is the ratio of alveolar pressure $\left(P_{\Delta}\right)$ to airflow $(V)$ at a particular time. Since airflow can be measured readily with a pneumotachograph, the method of measuring airway resistance presented in this 
paper centers on the determination of alveolar pressure as it exists during airflow. The general principle of the method is as follows: The subject sits and breathes inside an airtight box (body plethysmograph) similar to those which have been used to estimate the volume of gas in the lungs (10) or abdomen (11) by application of Boyle's law relating gas volumes and pressures. If there were no airway resistance, the alveolar pressure would be equal to the ambient pressure in the plethysmograph throughout the respiratory cycle and neither pressure would fluctuate, provided the $R$. Q. were 1 and there were no change in temperature or saturation of the gas in the plethysmograph-lung system. However, to make gas flow through the airway during expiration, alveolar pressure must exceed box pressure and to make gas flow during inspiration, alveolar pressure must be less than box pressure. Since the total amount of gas in the plethysmograph-lung system is constant, an increase in gas pressure inside the lungs of the subject, as during expiratory effort, must cause a decrease in pressure in the remainder of the gas in the plethysmograph. Therefore, at any instant, the resulting pressure change in the box must be opposite in sign to the pressure change in the lungs. By means of a very sensitive capacitance

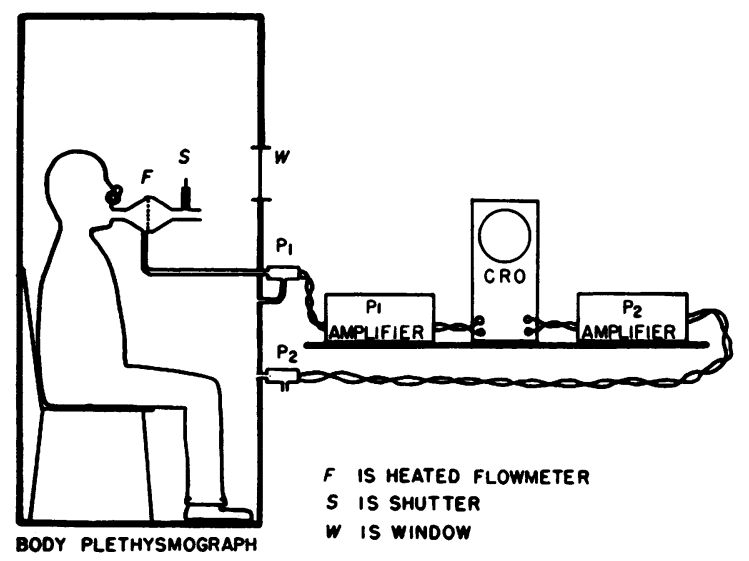

Fig. 1. Apparatus for Measurement of Airway Resistance

A. With shutter, $S$, open, air from plethysmograph is breathed through heated flowmeter, F. Flow is recorded on the $\mathrm{Y}$-axis of the cathode ray oscillograph, CRO, by means of pressure transducer, $P_{1}$. Simultaneous change in body volume is recorded on the $\mathrm{X}$-axis of the cathode ray oscillograph by means of pressure transducer, $P_{2}$. Alveolar gas is compressed during expiration and expanded during inspiration.

B. With shutter closed, there is no airflow. Mouth pressure (in equilibrium with pressure in the tracheobronchial tree) is recorded on the $\mathrm{Y}$-axis of $\mathrm{CRO}$ by means of pressure transducer, $P_{1}$. Change in body volume is recorded on the $\mathrm{X}$-axis of $\mathrm{CRO}$ by means of $\mathrm{P}_{2}$. Lung volume is computed by means of Boyle's law for gases.

Airway resistance is computed by combining the results of A (shutter open) and B (shutter closed). manometer, the pressure changes in the plethysmograph can be measured continuously during the respiratory cycle.

The measured value, change in plethysmographic pressure, can be used to calculate change in alveolar pressure if one also knows the initial alveolar gas volume and the initial alveolar pressure (which is assumed to be equal to atmospheric pressure at end expiration when there is no gas flow). However, this calculation is timeconsuming and airway resistance can be determined much more quickly by the following procedures: 1) Changes in airflow are plotted simultaneously against plethysmographic pressure changes (which are proportional to changes in alveolar pressure) on the two axes of a cathode ray oscillograph (CRO). 2) Immediately thereafter, changes in plethysmograph pressure are plotted against mouth pressure on the cathode ray oscillograph under static conditions, as the subject makes inspiratoryexpiratory efforts against a closed airway; since mouth pressure equals alveolar pressure in a static system, this second step serves to relate changes in plethysmograph pressure to changes in alveolar pressure in each subject. Thus, alveolar pressure is effectively measured during flow since the alveolar pressure for a given plethysmograph pressure is the same whether or not flow is interrupted provided the ratio of lung to plethysmograph gas volume is constant. The difference between this method and previous interrupter methods is that the interruption of flow in the present method is merely the means of calibrating the changes in plethysmograph pressure in terms of alveolar pressure; the values for resistance are always obtained during uninterrupted airflow. The details of the method will now be described:

1. Measurement of changes in pressure in the body plethysmograph simultaneously with flow: The plethysmograph is a metal chamber with the proportions of a telephone booth but having an air tight door; its internal volume is approximately 600 liters. Attached to this box is a sensitive Lilly capacitance manometer ${ }^{2}$ which responds to a pressure of $0.05 \mathrm{~cm}$. $\mathrm{H}_{2} \mathrm{O}$ by one inch horizontal deflection on a cathode ray oscillograph; 3 it measures pressure changes in the box with reference to atmospheric pressure (Figure 1).

The subject sits inside and breathes the air in this closed chamber. The box can be vented to the atmosphere by a valve. ${ }^{4}$ At the end of the two-minute warm up time, the subject, who wears a noseclip, places his mouth on a flowmeter-shutter apparatus (which is suspended from the box ceiling by means of curtain rods with spring sockets) and pants to and fro for 5 to 15 sec. through the flowmeter ${ }^{5}$ (volume 0.3 liter and sensi-

2 Lilly capacitance manometer, Technitrol Engineering Co., Philadelphia, Pa.

3 Cathode Ray Oscillograph, Type 304 A, Allen B. Dumont Co., Clifton, N. J.

4 Solenoid valve, Automatic Switch Co., Orange, New Jersey.

5 Flowmeter, Technitrol Engineering Co., Philadelphia, $\mathrm{Pa}$. 
tivity 1.34 liters per sec. per in. deflection) which is warmed by an electric current passing through a loop of nichrome wire.

When the subject breathes, airflow is recorded on the $Y$-axis of the cathode ray oscillograph and plethysmograph pressure (which is proportional to alveolar pressure) is recorded on the $\mathrm{X}$-axis; the slope of the line generated on the cathode ray oscillograph is $V / P_{P}$ where $V$ is airflow and $P_{P}$ is plethysmograph pressure (Figure 2).

Breaths of normal tidal volume produce an artefact caused by the instantaneous warming and wetting of inspired air and the cooling and condensation of expired air; because the rate of the latter is less than of the former, this produces a net effect in the direction of increased pressure in the box with each breath. Shallow breathing through the heated flowmeter reduces the size of the artefact. As long as the front between plethysmograph air and pulmonary air remains inside the metallic heated flowmeter, this artefact is eliminated. This artefact is also eliminated when the subject rebreathes in a rubber bag containing hot water, which serves to keep the respired air at constant conditions of temperature and saturation throughout the respiratory cycle.

Although most previous investigators using other methods have measured resistance to breathing at a normal breathing frequency and tidal volume, rapid, shallow breathing such as panting has certain theoretical and practical advantages: It minimizes the temperature, saturation and $R$. $Q$. effects to the extent that they can be neglected. It improves the signal to drift ratio because it allows completion of each respiratory cycle in a fraction of a second. Gradual thermal changes and very small leaks in the box become insignificant compared to

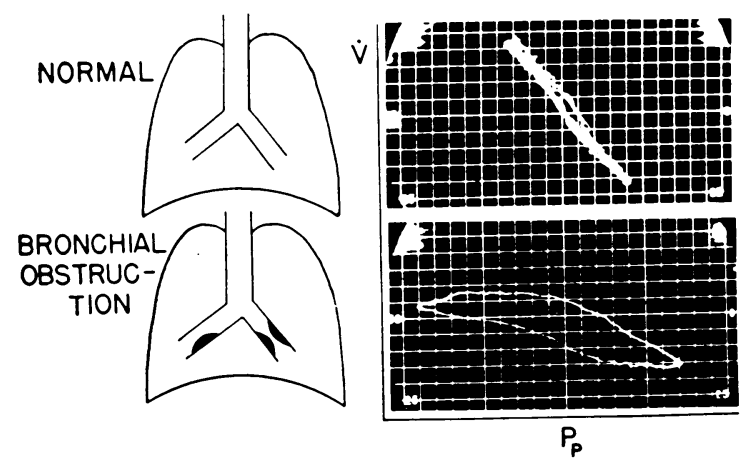

Fig. 2. Photograph of Cathode Ray Screen (Shutter OPEN)

Airflow on the $Y$-axis has calibration of $1.3 \mathrm{~L}$. per sec. per inch deflection. Change in body volume on the $\mathrm{X}$-axis has calibration of $14 \mathrm{cc}$. per inch deflection (normal subject), and $27 \mathrm{cc}$. per inch, case No. 20, bronchial obstruction. Zero flow is in center of screen. Although a simple ' $\mathrm{S}$ ' shaped resistance line was characteristic of normal subjects, patients who had predominantly expiratory obstruction generally showed the looping of resistance, which was increased in association with expiratory flow, or volume, as in this case, or both.
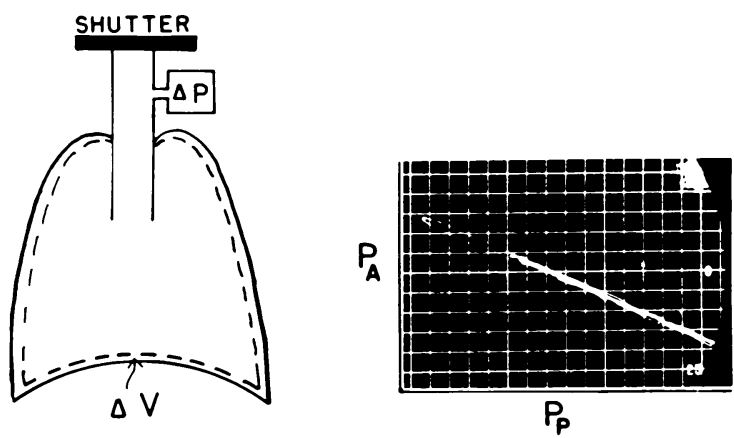

Fig. 3. Photograph of Cathode Ray Screex (Shltter Closed)

Mouth pressure on $\mathrm{Y}$-axis has calibration of $7.1 \mathrm{~cm}$. $\mathrm{H}_{2} \mathrm{O}$ per inch deflection. Change in body volume on the $\mathrm{X}$-axis has calibration of $14 \mathrm{cc}$. per inch deflection. Atmospheric pressure in center of screen. Grid lines in Figure 2 and Figure 3 are 0.2 inch.

the volume changes attributable to compression and decompression of alveolar gas.

Certain objections may be raised to the use of panting: a) The volume of gas in the lungs during panting is often different from the volume during quiet breathing because the subject chooses a lung volume which offers the least sensation of obstruction to breathing, b) the subject may tend to open maximally his upper airway (mouth and glottis), c) the subject breathes so shallowly that gas distribution is not limited by stiff regions of the lung, but the gas follows only the pathways of least resistance and d) panting at very low tidal volumes leads to a rise in $\mathrm{PCO}_{2}$ and a decrease in $\mathrm{PO}_{2}$ in the airways during the period of the test. On the other hand it has been shown that the over-all resistance to breathing can be measured by a pump at 6 cycles per second (12), that the frequency response of the chest wall is satisfactory in this frequency range (13) and that respiratory resistance measured in cats is not different when measured at high and low frequencies (14). However, further studies are needed to determine the exact magnitude of changes in airway resistance produced by the panting procedure per se. The present measurements of airway resistance were made at panting frequencies which were approximately 2 cycles per second. This frequency is well within the limit of both capacitance manometers since their frequency responses were flat to at least 35 cycles per second.

2. Mcthod of relating plethysmographic pressure changes to alieolar pressure changes: To relate changes in plethysmograph pressure to changes in alveolar pressure, the following procedure is performed: The operator activates a rotary solenoid (9) which occludes the distal end of the flowmeter. The subject continues to pant and records are made continuously of mouth pressure ( $\mathrm{Y}$ axis) and plethysmograph pressure ( $\mathrm{X}$ axis) (Figure 3 ). (The pressure gauge ${ }^{6}$ formerly used to record differential

${ }^{6}$ Venous pressure head, Technitrol Engineering Co., Philadelphia, $\mathrm{Pa}$. 
pressure across the flowmeter now measures mouth pressure with respect to box pressure. Ideally, it should now measure mouth pressure with respect to atmospheric. The 1 per cent error was insufficient to warrant the technical difficulty of changing over the back side of the gauge. However it is necessary to reduce the sensitivity of this gauge by a factor of ten at the same time that the rotary solenoid is activated; its sensitivity is now $7 \mathrm{~cm}$. $\mathrm{H}_{2} \mathrm{O}$ per inch deflection.) Since there is no airflow during the period of occlusion, mouth pressure equals alveolar pressure and the slope of the line generated on the cathode ray oscillograph is now $P_{\Delta} / P_{P}$ where $P_{\Delta}$ is alveolar pressure and $P_{P}$ is plethysmograph pressure. Since the same manometer is used to record $P_{P}$ both with the shutter open and closed, $P_{P}$ of both slopes is the same.

The lines produced on the oscilloscope are traced 7 or photographed (f 5.6, bulb exposure, Plus-X film, with plus 2 diopter supplementary lens) or both. The total time in the box is approximately 5 minutes. The flowmeter is then calibrated with a recording spirometer to measure airflow and the mouth pressure gauge is calibrated with a water manometer.

3. Calculation of airway resistance: To determine the airway resistance, it is necessary to know the ratio of alveolar pressure to airflow at the mouth, $P_{A} / V$. The experiments yielded two slopes. First, with the shutter open, the slope $V / P_{P}$ was measured on the $S$ shaped line from the point of 1 liter per second of inspiratory flow to the point of 1 liter per second of expiratory flow. ${ }^{8}$ Second, the slope $P_{A} / P_{P}$ is generated with the shutter closed. The total airway resistance is calculated by taking the ratio of slopes :

$$
\mathrm{R}=\frac{\mathrm{P}_{\mathrm{A}} / \mathrm{P}_{\mathrm{P}}}{\dot{\mathrm{V}} / \mathrm{P}_{\mathrm{P}}}
$$

where $P_{A}$ is alveolar pressure, $V$ is airflow, $P_{P}$ is plethysmograph pressure (the same with shutter open and closed), and $R$ is resistance.

A correction is made on the total airway resistance for the volume of the dead space by assuming that the average resistance to airflow is halfway down the tracheobronchial tree: The slope $P_{\Delta} / P_{P}$ is multiplied by the ratio of total gas volume occluded by the shutter to gas volume proximal to the point of mean resistance to gas flow. The total volume is measured immediately at the end of the test by the plethysmographic method (15). The volume proximal to the resistance is the total volume minus the volume of the flowmeter $(0.3$ liter $)$ and half the volume of the tracheobronchial tree $(0.1$ liter $)$. Resistance of the flowmeter-shutter breathing apparatus is

7 "Oscillotracer," R. A. Waters, Inc., Waltham, Mass. 8 Some subjects showed increased end expiratory resistance, forming a loop in the appropriate portion of the pressure-flow curve. This loop was probably caused by partial or complete collapse of some of the air passages as the subject expired toward residual volume. In these subjects the mean slope was measured after drawing a line along the imaginary center, or long axis of the loop. measured ( 0.5 to $0.7 \mathrm{~cm} . \mathrm{H}_{2} \mathrm{O}$ per liter per sec.) and subtracted from the total airway resistance to obtain airway resistance of the subject. The values for airway resistance are expressed in $\mathrm{cm} . \mathrm{H}_{2} \mathrm{O}$ per liter per sec.

4. Experimental accuracy: The method of tracing and reading the image from the cathode ray oscillograph permits a 5 per cent error of slope. Since two different slopes are used in the calculation of resistance, the sum of the errors may be 10 per cent. There is a slight reading error in calibration of the flowmeter and mouth pressure gauge; however errors in calibration of the box pressure gauge are automatically cancelled in the calculation of resistance. Since these reading errors are of a random nature, the over-all accuracy is improved by repeating the measurement of airway resistance several times and averaging the results.

The advantage of tracing is that it permits calculation of the airway resistance without delay; however the slopes can be read more accurately from a photograph than from a pencil tracing.

5. Validity: The validity of the plethysmograph method for airway resistance was tested by determining the total resistance before and after various degrees of resistance were interposed between the flowmeter and the subject's mouth. The added resistances were $2.7,5.9$, and $10.9 \mathrm{~cm}$. $\mathrm{H}_{2} \mathrm{O}$ per liter per sec.; these caused an increase in airway resistance as measured by the plethysmograph method of $2.2,5.9$, and $9.3 \mathrm{~cm}$. $\mathrm{H}_{2} \mathrm{O}$ per liter per second, respectively. The discrepancies were within the combined reading errors of the methods for measuring the values of the added resistances and the airway resistance.

6. Other possible sources of error: Since the total gas volume, which is used to correct for the volume of the dead space in calculating resistance is determined by a plethysmograph method (15), a gross check of this method was done as follows: The total gas volume was determined before and after the subject inspired measured volumes from a recording spirometer. The inspired volumes were 1.1 liters, 2.4 liters, and 3.7 liters and the compressible gas was found to increase by 1.0 liters, 2.2 liters, and 3.5 liters, respectively. The presence of abdominal gas might conceivably produce an error in the calculated volume of compressible gas in the lungs. If the abdominal gas were compressed during expiration and expanded during inspiration, the total apparent compressible volume would be greater than the lung volume, whereas if the abdominal gas were expanded during expiration and compressed during inspiration, the calculated volume would be less than the lung volume. However, if the calculated gas volume during voluntary efforts against the closed shutter were equal to the calculated volume during voluntary panting through the flowmeter, there would be no error in the calculation of airway resistance, because the plethysmograph pressure terms which would be affected cancel during the calculation. Errors in box calibration are eliminated for the same reason. Abdominal pressure changes measured by a gastric balloon and box pressure were recorded on two normal subjects and four patients during panting through 
the flowmeter and against the closed shutter and the relationship between abdominal and box pressure showed no significant difference with the shutter open or closed. The calculated volume, shutter-open, would therefore be the same as with the shutter closed. The conclusion is that abdominal gas cancels out in the calculation of airway resistance. More detailed accounts of the accuracy of the plethysmographic method of determining thoracic gas volume and abdominal gas volumes will be the subject of separate reports $(15,16)$.

The R. Q. might conceivably produce an error in the determination of airway resistance by the plethysmographic method since there is a gradual absorption of gas when the mean R. $Q$. is less than 1.0. For example, if oxygen consumption is $300 \mathrm{cc}$. per minute and the $\mathrm{CO}_{2}$ output is $240 \mathrm{cc}$. per minute the mean R. Q. is 0.8 and the net gas absorption is $60 \mathrm{cc}$. per minute ("respiratory exchange difference") or $1 \mathrm{cc}$. per sec. During inspiration, the respiratory exchange difference is slightly greater, and during expiration, it is slightly less than the mean. Upon rebreathing the dead space gas, the respiratory fluctuations disappear, but the trend of the respiratory exchange differences changes, as in breath holding, causing a slight increase in the net rate of gas absorption. Neither the mean trend nor the respiratory fluctuations are large enough to interfere with the measurement of airway resistance or lung volume because, during panting, pressure changes are sufficiently rapid and the volume changes due to compression of lung air are large enough that the $R$. $Q$. effect is small by comparison, even in subjects with normal airway resistance.

7. Other tests: Those performed on the patients in- cluded vital capacity, maximal expiratory flow rate over the range 200 to $1,200 \mathrm{cc}$., maximal breathing capacity using a Tissot spirometer and lung compliance using an esophageal balloon, capacitance manometer, spirometer with potentiometer, and cathode ray oscillograph.

\section{RESULTS AND DISCUSSION}

\section{Normal subjects}

Twenty-one subjects who had no signs, symptoms, or history of respiratory disease were studied; ten of these were tested on two different days, and eleven were tested on only one day. The mean airway resistance of the 21 normal subjects was $1.5 \mathrm{~cm} . \mathrm{H}_{2} \mathrm{O}$ per liter per sec., at a flow of one liter per second, panting. The standard deviation was \pm 0.49 and the range 0.6 to 2.4 (Table I). In those subjects tested on two different days, the standard deviation of the mean of the differences between determinations was \pm 0.37 . Because this small series contains men and women in all age groups, breathing at different lung volumes, these data are presented only to give an approximate range of normal values; larger groups in all decades are now being studied in order to define normal values more precisely.

In this series, the sensitivity of the manometers was adjusted so that the most accurate readings

TABLE I

Airway resistance in normal subjects (panting) *

\begin{tabular}{|c|c|c|c|c|c|c|c|c|}
\hline \multirow[b]{2}{*}{ Subject } & \multirow{2}{*}{$\begin{array}{c}\text { Age } \\
\text { (yrs.) }\end{array}$} & \multirow[b]{2}{*}{ Sex } & \multirow{2}{*}{$\begin{array}{c}\text { Height } \\
(\text { ft., in. })\end{array}$} & \multirow{2}{*}{$\begin{array}{l}\text { Weight } \\
\text { (pounds) }\end{array}$} & \multicolumn{2}{|c|}{$\begin{array}{c}\text { Plethysmographic } \\
\text { thoracic gas volume } \\
\text { (liters, BTPS) }\end{array}$} & \multicolumn{2}{|c|}{$\begin{array}{l}\text { Airway resistance } \\
\left(\mathrm{cm} . \mathrm{H}_{2} \mathrm{O} / \mathrm{L} . / \mathrm{sec} .\right)\end{array}$} \\
\hline & & & & & No. 1 & No. 2 & No. 1 & No. 2 \\
\hline 1. F. K. & 33 & $\mathbf{M}$ & $5^{\prime} 10^{\prime \prime}$ & 165 & 3.9 & 3.9 & 1.6 & 1.3 \\
\hline 2. J. M. & 32 & $\mathbf{M}$ & $5^{\prime} 5^{\prime \prime}$ & 133 & 2.4 & 2.8 & 1.6 & 1.3 \\
\hline 3. L. C. & 28 & $\mathbf{M}$ & $5^{\prime} 9 \frac{1}{2}=$ & 180 & 5.3 & 1.8 & 1.4 & 1.7 \\
\hline 4. E. H. & 30 & $\mathrm{~F}$ & $5^{\prime} 4^{\frac{3}{4}}$ & 137 & 2.0 & 2.3 & 2.1 & 1.7 \\
\hline 5. L. D. & 28 & $\mathbf{M}$ & $5^{\prime} 7^{\prime \prime}$ & 160 & 3.0 & 2.7 & 1.6 & 1.8 \\
\hline 6. P. C. & 23 & $F$ & $5^{\prime} 3^{\prime \prime}$ & 101 & 2.4 & 2.8 & 1.8 & 1.1 \\
\hline 7. M.E. & 22 & $F$ & $5^{\prime} 10^{\prime \prime}$ & 145 & 3.5 & 4.0 & 1.4 & 1.3 \\
\hline 8. A. V. & 40 & M & $6^{\prime} \frac{1}{2}=$ & 190 & 3.4 & 5.2 & 1.1 & 0.7 \\
\hline 9. C. C. & 29 & M & $5^{\prime} 9^{\prime \prime}$ & 145 & 3.6 & 3.5 & 2.0 & 1.7 \\
\hline 10. A. D. & 30 & M & $6^{\prime} 3^{\prime \prime}$ & 200 & 2.9 & 3.7 & 1.3 & 1.8 \\
\hline 11. B. L. & 29 & $\mathbf{M}$ & $5^{\prime} 11^{\prime \prime}$ & 175 & 5.2 & - & 1.4 & 一 \\
\hline 12. J. T. & 29 & $\mathrm{~F}$ & $5^{\prime} 5^{\prime \prime}$ & 110 & 1.9 & - & 1.9 & - \\
\hline 13. D. T. & 28 & $F$ & $4^{\prime} 10^{\prime \prime}$ & 93 & 2.4 & - & 2.4 & - \\
\hline 14. E. B. & 37 & M & $5^{\prime} 10 \frac{1}{2}{ }^{\prime \prime}$ & 160 & 4.5 & - & 0.6 & - \\
\hline 15. M. J. & 51 & M & $5^{\prime} 11^{\prime \prime}$ & 185 & 4.2 & - & 0.9 & - \\
\hline 16. S. D. & 57 & $\mathbf{M}$ & $5^{\prime} 3^{\prime \prime}$ & 150 & 3.0 & - & 2.3 & 一 \\
\hline 17. R. N. & 37 & M & $5^{\prime} 11^{\prime \prime}$ & 150 & 3.7 & - & 1.7 & - \\
\hline 18. M. M. & 33 & $\mathbf{M}$ & $6^{\prime} 3^{\prime \prime}$ & 185 & 3.9 & - & 1.0 & - \\
\hline 19. R. C. & 51 & M & $5^{\prime} 10 \frac{1}{2}{ }^{\prime \prime}$ & 168 & 5.4 & - & 0.9 & - \\
\hline $\begin{array}{l}\text { 20. C. M. } \\
\text { 21. R. D. }\end{array}$ & 35 & M & $6^{\prime} 1^{\prime \prime}$ & 150 & 4.8 & - & 1.9 & - \\
\hline & 27 & $\mathbf{F}$ & $5^{\prime} 8 \frac{1}{2}=$ & 117 & 3.5 & - & 1.3 & - \\
\hline
\end{tabular}

* Subjects 1-21, mean airway resistance $=1.50 \mathrm{~cm} . \mathrm{H}_{2} \mathrm{O}$ per L. per sec., S.D. \pm 0.49 . Subjects $1-10$, mean of the differences between No. 1 and No. 2 measurements of airway resistance $=0.15 \mathrm{~cm}$. $\mathrm{H}_{2} \mathrm{O}$ per L. per sec., S.D. \pm 0.37 . 
of the S-shaped curve on the cathode ray oscillograph were made at flow rates of 1 liter per sec. Mean values of airway resistance measured at flow rates of 0.75 liter per sec. are approximately 0.1 $\mathrm{cm} . \mathrm{H}_{2} \mathrm{O}$ per liter per sec. less and those measured at 0.5 liter per sec. are approximately $0.2 \mathrm{~cm}$. $\mathrm{H}_{2} \mathrm{O}$ per liter per sec. less than values obtained at flow rates of 1.0 liter per sec. The values obtained represent those for a specific pattern of mouth breathing; the resistance to airflow through the nasal passages may be appreciable as indicated by measurements of pressure differential between nasopharynx and one nostril, which we have found to range from 1 to $4 \mathrm{~cm}$. $\mathrm{H}_{2} \mathrm{O}$ per liter per sec. at

TABLE II

Airway resistance in thirty patients

\begin{tabular}{|c|c|c|c|c|c|c|c|c|c|c|c|}
\hline Subject & $\begin{array}{c}\text { Age } \\
(y r s .) \\
\text { and sex }\end{array}$ & Disease & $\begin{array}{c}\text { Dura- } \\
\text { tion of } \\
\text { disease } \\
(y r s .)\end{array}$ & $\begin{array}{c}\text { Chief } \\
\text { symptom* }\end{array}$ & $\begin{array}{l}\text { Vital } \\
\text { capac- } \\
\text { ity } \\
(L .)\end{array}$ & $\begin{array}{l}\text { Max. } \\
\text { expir. } \\
\text { flow } \\
\text { rate } \\
(L . / \text { min. })\end{array}$ & $\begin{array}{l}\text { Max. } \\
\text { breath- } \\
\text { ing } \\
\text { capacity } \\
(\text { L./min. })\end{array}$ & $\begin{array}{c}\text { Lung } \\
\text { compli- } \\
\text { ance } \\
(L . / c m . \\
\left.\mathrm{H}_{2} \mathrm{O}\right)\end{array}$ & $\begin{array}{c}\text { Plethys- } \\
\text { mographic } \\
\text { thoracic } \\
\text { gas } \\
\text { volume } \\
(L .) \\
\end{array}$ & $\begin{array}{c}\text { Airway } \\
\text { resist. } \\
(\mathrm{cm} . \mathrm{H} \cdot \mathrm{O} / \\
L . / \mathrm{sec} .)\end{array}$ & $\begin{array}{c}\text { Measured } \\
\text { at flow } \\
\text { rate of } \\
(L . / \text { sec. })\end{array}$ \\
\hline 1. W. M. & $42 \mathrm{M}$ & ? Silicosis & 2 & DOE, slight & 4.6 & 530 & 168 & 0.22 & 3.9 & 1.9 & 1.0 \\
\hline 2. E. M. & $48 \mathrm{~F}$ & Scleroderma & 3 & Cough & 2.1 & 170 & 114 & & 3.0 & 1.6 & 1.0 \\
\hline 3. R. D. & $44 \mathrm{M}$ & $\begin{array}{l}\text { Scleroderma } † \\
\text { (biopsy) }\end{array}$ & 3 & $\begin{array}{l}\text { Dyspnea, } \\
\text { occasional }\end{array}$ & 1.5 & & 145 & 0.04 & 1.6 & 0.6 & 0.9 \\
\hline 4. M. C. & $44 \mathrm{~F}$ & Chr. bronchitis & & DOE & 2.4 & & & 0.15 & 3.5 & 5.5 & 0.8 \\
\hline 5. J. L. & $65 \mathrm{~F}$ & Asthma & 31 & DOE, $1 \mathrm{flt}$. & 2.5 & 72 & & 0.08 & 4.1 & $9.8,7.0 \S$ & 0.7 \\
\hline 6. J. C. & $55 \mathrm{M}$ & $\begin{array}{l}\text { Asthma and } \\
\text { stenosis of } \\
\text { the glottis } \ddagger\end{array}$ & 25 & $\begin{array}{l}\text { Parox. } \\
\text { dyspnea }\end{array}$ & 4.5 & 124 & 43 & & 3.5 & 7.2 & 1.0 \\
\hline 7. N.P. & $56 \mathrm{M}$ & Chr. bronchitis $\ddagger$ & 18 & $\begin{array}{l}\text { DOE and } \\
\text { cough }\end{array}$ & 3.4 & 93 & 44 & & 7.3 & 3.4 & 1.0 \\
\hline 8. W. H. & $54 \mathrm{M}$ & Asthma & 21 & DOE & 3.3 & 29 & & 0.26 & 6.7 & 5.2 & 0.9 \\
\hline 9. I. B. & $67 \mathrm{M}$ & Asthma & 12 & $\begin{array}{l}\text { Dyspnea } \\
\text { at rest }\end{array}$ & 1.8 & 22 & 22 & 0.06 & 6.5 & $\begin{array}{l}6.8 \\
1.9 \|\end{array}$ & 0.58 \\
\hline 10. J. J. & $56 \mathrm{M}$ & Asthma & 37 & DOE, $1 \mathrm{flt}$. & 2.4 & 17 & & & 3.7 & 6.8 & 0.68 \\
\hline 11. A. A. & $64 \mathrm{~F}$ & Asthma & 15 & $\begin{array}{l}\text { DOE, occa- } \\
\text { sional }\end{array}$ & 2.0 & 115 & & & 2.8 & 3.1 & 0.5 \\
\hline 12. C. C. & $54 \mathrm{M}$ & Pulm. fibrosis ${ }_{t}+$ & 1 & "Chest cold" & 1.2 & 260 & 50 & 0.011 & 2.6 & 2.8 & 0.7 \\
\hline 13. S. T. & $21 \mathrm{M}$ & Asthma & & Asympt. & 5.5 & 270 & & 0.21 & 2.9 & 3.2 & 0.8 \\
\hline 14. C. K. & $63 \mathrm{~F}$ & Asthma & 12 & $\begin{array}{c}\text { Dyspnea } \\
\text { at rest }\end{array}$ & 1.5 & 58 & & 0.05 & $\begin{array}{l}2.6 \\
2.3\end{array}$ & $\begin{array}{l}6.8 \S \\
6.8\end{array}$ & 0.7 \\
\hline 15. B. J. & $38 \mathrm{M}$ & Asthma & 30 & $\begin{array}{c}\text { Dyspnea } \\
\text { at rest }\end{array}$ & 1.9 & 13 & & 0.06 & $\begin{array}{l}5.6 \\
5.5\end{array}$ & $\begin{array}{l}7.5 \S \\
6.9\end{array}$ & 0.5 \\
\hline 16. R. H. & $51 \mathrm{M}$ & Asthma & & $\begin{array}{l}\text { Dyspnea, } \\
\text { slight }\end{array}$ & 2.1 & 44 & & 0.13 & 6.1 & 5.9 & 0.8 \\
\hline 17. L. B. & $53 \mathrm{M}$ & Asthma & 47 & $\begin{array}{l}\text { Dyspnea, } \\
\text { occasional }\end{array}$ & 2.6 & 35 & & 0.27 & 5.1 & 4.5 & 0.9 \\
\hline 18. E. N. & $42 \mathrm{~F}$ & Asthma & & Asympt. & 2.2 & 77 & 43 & 0.20 & 3.5 & 3.9 & 0.7 \\
\hline 19. G. D. & $53 \mathrm{M}$ & Emphysema & 3 & DOE, slight & 2.6 & 66 & & 0.11 & 5.6 & 7.7 & 0.5 \\
\hline 20. W. L. & $51 \mathrm{M}$ & Silicosis & 11 & DOE, 1 flt. & 2.1 & 19 & 26 & 0.14 & 5.1 & 10.8 & 0.5 \\
\hline 21. S. S. & $63 \mathrm{~F}$ & Asthma & & Asympt. & 2.2 & 49 & & 0.08 & 3.9 & 8.3 & 0.7 \\
\hline 22. B. J. & $28 \mathrm{M}$ & Asthma & 10 & Dyspnea & 2.3 & 19 & & & 6.0 & 4.7 & 0.9 \\
\hline 23. M. H. & $9 \mathrm{~F}$ & Pulm. fibrosis & 1 & $\begin{array}{l}\text { Dyspnea, } \\
\frac{1}{2} \mathrm{flt} \text {. } \\
\text { Resp. rate } \\
72 / \text { min. }\end{array}$ & 0.2 & & & & 1.0 & 5.2 & 0.6 \\
\hline 24. J. H. & $61 \mathrm{M}$ & Pneumoconiosis & 9 & DOE, 1 block & 2.4 & 26 & 60 & & 4.6 & 6.4 & 0.5 \\
\hline 25. M. C. & $62 \mathrm{M}$ & Pneumoconiosis & 2 & DOE, $1 \mathrm{flt}$. & 3.1 & 99 & 46 & & 4.8 & 2.3 & 0.5 \\
\hline 26. H. P. & $44 \mathrm{M}$ & Asthma & 16 & Asympt. & 2.6 & 132 & & & 3.2 & 2.2 & 0.9 \\
\hline 27. E. C. & $47 \mathrm{~F}$ & Hay fever & 30 & Asympt. & 2.8 & 140 & & & 3.2 & 2.2 & 0.5 \\
\hline 28. G. L. & $58 \mathrm{M}$ & $\begin{array}{l}\text { "Alveolar } \\
\text { cell" Ca† }\end{array}$ & 1 & DOE, severe & 0.9 & & 72 & 0.013 & 2.1 & 2.2 & 0.7 \\
\hline $\begin{array}{l}\text { 29. L. F. } \\
\text { 30. E. W. }\end{array}$ & $55 \mathrm{M}$ & Asthma ? & 17 & Asympt. & 1.9 & $57 ?$ & & 0.12 & 4.1 & 1.7 & 0.7 \\
\hline & $26 \mathrm{~F}$ & Normal preg. & 0.7 & Asympt. & & & & & 3.7 & 2.6 & 1.0 \\
\hline
\end{tabular}

$*$ DOE $=$ Dyspnea on exertion; flt. = flight.

$\dagger$ Biopsy of lung showed: No. 3, interstitial fibrosis; No. 12, pulmonary fibrosis; autopsy showed: No. 28, no tracheobronchial obstruction.

$\ddagger$ Bronchoscopy showed: No. 4, chronic tracheobronchitis; No. 5, bronchiectasis and purulent tracheobronchitis; No. 6, stenosis of glottis (laryngoscopy); No. 7, bilateral tracheobronchitis; No. 8, allergic tracheobronchitis; No. 12, no abnormalities.

$\S$ Patients 5,14 and 15 , airway resistance measurement was repeated on a subsequent day.

|l After subcutaneous injection of epinephrine. 
flow rates of 0.25 liter per sec. in normal subjects with no subjective complaints of nasal obstruction. Therefore the resistance of the total airway in subjects breathing through the nose would be greater than the values obtained in this study. The resistance predicted by Rohrer from anatomical measurements of the tracheobronchial tree in a cadaver was $1.6 \mathrm{~cm}$. $\mathrm{H}_{2} \mathrm{O}$ per liter per sec. It is not possible to make a comparison of these data with data obtained by other investigators using different methods for several reasons: a) Some of the methods purporting to measure airway resistance alone actually include other factors as well and are not specific tests of airway resistance, $b$ ) the specific breathing pattern used in this test differs from that used by other investigators. However, a comparison with the esophageal pressure method for pulmonary resistance, reported in detail in reference 17 , yielded mean normal pulmonary tissue resistance of approximately $0.2 \mathrm{~cm}$. $\mathrm{H}_{2} \mathrm{O}$ per liter per second at 0.5 liter per second.

\section{Patients with respiratory disease}

No attempt will be made here to present a complete analysis of the mechanical factors in breathing in patients with respiratory disease. However this test for airway resistance has been applied to a sufficient number of patients to evaluate its practicality, limitations and usefulness in diagnosis and treatment.

The method cannot of course be used in patients who are too sick or too weak to sit in the plethysmograph. Patients with bilateral paralysis of the lower extremities would have to be lifted in and out of the box. No patients refused to enter the box but one "normal" subject refused to enter the box because of claustrophobia. Several patients were unable to breathe at flow rates as great as 1.0 liter per sec.; in these the resistance was calculated at flow rates of 0.5 to 1.0 liter per sec. Many of the patients with high resistance showed loops similar to that in Figure 2, bottom, compatible with expiratory obstruction. The 30 patients, including one child aged nine years, studied in this series were all able to follow directions and complete the test satisfactorily. Data obtained upon these 30 patients are presented in Table II and Figure 4. Since there is no other method available for direct measurement of airway

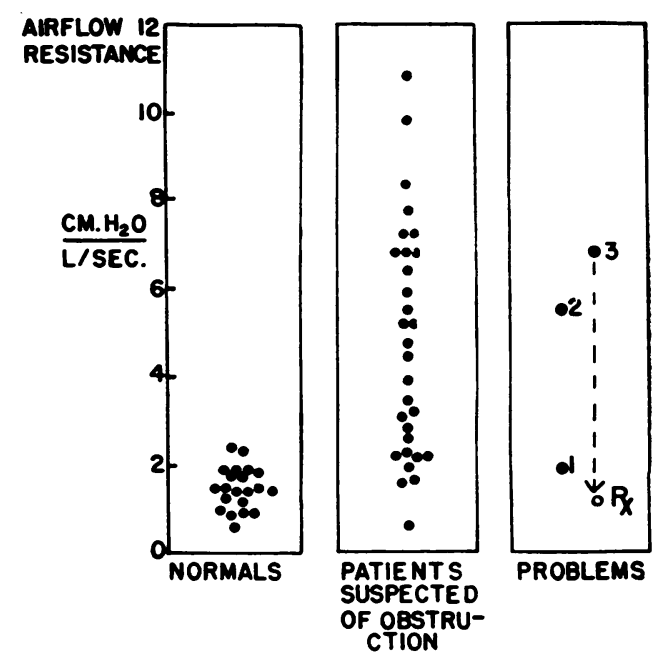

Fig. 4. Summary of Airway Resistance Values in Normal Subjects, Patients with Suspected Obstruction and in Three Problem Cases

The three problem cases are as follows:

1. W. M. Case No. 1 (Table II), was referred for evaluation of possible pulmonary disability due to suspected pneumoconiosis: Objective pulmonary function tests were of value in ruling out impairment of function.

2. M. C. Case No. 4 (Table II), was tested to distinguish between dyspnea accompanying anxiety versus organic disease. This method revealed evidence of organic tracheobronchial obstruction.

3. I. B. Case No. 9 (Table II), was evaluated for effect of bronchodilator drugs on respiratory obstruction. It was found that his obstruction was not of the 'fixed' type, but reversible by administration of epinephrine subcutaneously.

resistance, the reliability of this method cannot be checked experimentally except for evidence of false positive or false negative indication of tracheobronchial obstruction. For example, since patients 1 to 3 had a maximal breathing capacity in the normal range, it is unlikely that they had any significant increase in airway resistance; their values ( 0.6 to $1.9 \mathrm{~cm} . \mathrm{H}_{2} \mathrm{O}$ per liter per sec.) fell in the normal range. Patients 4 to 8 had known partial obstruction in their large airways by bronchoscopic examination and all had increased airway resistance by the present test.

The values for airway resistance in patients 9 to 24 were increased and in all of these there were clinical reasons for expecting either increased airway or tissue resistance. Patients 25 to 28 were borderline cases with high normal values for airway resistance and clinical findings suggestive of 
partial obstruction. Patient 29 had airway resistance within one standard deviation of the normal mean, but his maximal expiratory flow rate was less than normal. This means that the low value for maximal expiratory flow rate was caused by factors other than increased airway resistance; some of these might be partial collapse of the intrathoracic portion of the tracheobronchial tree during forced expiration (which would not occur with the present test), by increased resistive factors in the chest wall or lung tissues, or by failure to exert maximal force. The finding of slightly increased airway resistance in patient 30 is not readily explained although it is possible that this slightly increased airway resistance might be the result of distortion of the airways as a result of the pregnancy; further studies must be done on a large group before any conclusions can be drawn.

No attempt will be made to correlate airway resistance measured by this test with maximal breathing capacity, timed vital capacity, or maximal expiratory flow rates, since these last named tests are "over-all" tests of mechanical factors during forced breathing and include many factors in addition to the specific airway resistance being measured here.

It appears that this method of measuring airway resistance alone has the following uses: a) Objective measurement of airway resistance in patients ; it has the advantage of measuring one specific component of the mechanical factors in breathing, without the requirement of maximal respiratory effort on the part of the patient; b) Quantitative and objective evaluation of therapeutic procedures designed to relieve airway obstruction; c) Separate measurement of airway resistance so that tissue resistance can be determined as the difference between total resistance and airway resistance; d) Study of multiple physiological, pharmacological and environmental and pathological factors that may affect airway resistance.

\section{SUMMARY}

A new method is reported for the objective and specific measurement of airway resistance in human subjects. It requires the measurement of airflow and of alveolar pressure during airflow; the latter is measured by determining by means of a body plethysmograph the volume of compression and decompression of alveolar gas during expiration and inspiration.

Normal subjects tested by this method had a mean airway resistance of $1.5 \mathrm{~cm} . \mathrm{H}_{2} \mathrm{O}$ per liter per sec. (range 0.6 to 2.4) at a flow rate of 1 liter per second, panting. A preliminary study has been made of the airway resistance in 30 patients; the range of resistances was 0.6 to $10.8 \mathrm{~cm}$. $\mathrm{H}_{2 .} \mathrm{O}$ per liter per sec.

This method is thought to be applicable to measurement of airway resistance in patients, evaluation of therapeutic procedures designed to relieve airway obstruction, separation of airway resistance from tissue resistance, and study of multiple factors that may affect airway resistance.

\section{REFERENCES}

1. Rohrer, F., Der Strömungswiderstand in den menschlichen Atemwegen und der Einfluss der unregelmässigen Verzeweigung des Bronchialsystems auf den Atmungsverlauf in verschiedenen Lungenbezirken. Arch. f. d. ges. Physiol., 1915, 162, 225.

2. von Neergaard, K., and Wirz, K., Uber eine Methode zur Messung der Lungenelastizität am lebenden Menschen, insbesondere beim Emphysem. Ztschr. f. klin. Med., 1927, 105, 35.

3. Bayliss, L. E., and Robertson, G. W., The visco-elastic properties of the lungs. Quart. J. Exper. Physiol., 1939, 29, 27.

4. Fry, D. L., Ebert, R. V., Stead, W. W., and Brown, C. C., The mechanics of pulmonary ventilation in normal subjects and in patients with emphysema. Am. J. Med., 1954, 16, 80.

5. McIlroy, M. B., Mead, J., Selverstone, N. J., and Radford, E. P., Measurement of lung tissue viscous resistance using gases of equal kinematic viscosity. J. Applied Physiol., 1955, 7, 485.

6. von Neergaard, K., and Wirz, K., Die Messung der Strömungswiderstände in den Atemwegen des Menschen, insbesondere bei Asthma und Emphysem. Ztschr. f. klin. Med., 1927, 105, 51.

7. Vuilleumier, P., Uber eine Methode zur Messung des intraalveolären Druckes und der Strömungswiderstände in den Atemwegen des Mensches. Ztschr. f. klin. Med., 1944, 143, 698.

8. Otis, A. B., Fenn, W. O., and Rahn, H., Mechanics of breathing in man. J. Applied Physiol., 1950, 2, 592.

9. Mead, J., and Whittenberger, J. L., Evaluation of airway interruption technique as a method for measuring pulmonary air-flow resistance. J. Applied Physiol., 1954, 6, 408.

10. Pflüger, E., Das Pneumonometer. Arch. f. d. ges. Physiol., 1882, 29, 244. 
11. Blair, H. A., Dern, R. J., and Bates, P. L., Measurement of volume of gas in the digestive tract. Am. J. Physiol., 1947, 149, 688.

12. DuBois, A. B., Resistance to breathing measured by driving the chest at 6 cps. Federation Proc., 1953, $12,35$.

13. DuBois, A. B., Brody, A. W., Lewis, D. H., and Burgess, B. F., Jr., Response of the chest wall, abdomen and diaphragm to forced oscillations of volume. Federation Proc., 1954, 13, 38.

14. Nisell, O. I., and DuBois, A. B., Relationship between compliance and FRC of the lungs in cats, and measurement of resistance to breathing. Am. J. Physiol., 1954, 178, 206.
15. DuBois, A. B., Botelho, S. Y., Bedell, G. N., Marshall, R., and Comroe, J. H., Jr., A rapid plethysmographic method for measuring thoracic gas volume: A comparison with a nitrogen washout method for measuring functional residual capacity in normal subjects. J. Clin. Invest., 1956, 35, 322.

16. Bedell, G. N., Marshall, R., DuBois, A. B., and Harris, J. H., Measurement of the volume of gas in the gastro-intestinal tract. Values in normal subjects and ambulatory patients. J. Clin. Invest., 1956, 35, 336.

17. Marshall, R., and DuBois, A. B., The measurement of the viscous resistance of the lung tissues in normal man. Clin. Sc., 1956. 